\title{
THE ROLE OF HUMAN FACTOR IN THE DEVELOPMENT OF AGRICULTURE IN MONTENEGRO
}

\author{
Žarko Božović ${ }^{1}$, Jovan Đurašković ${ }^{2}$
}

\begin{abstract}
Summary
We have started from the analysis of existing human resources in the paper, from the point of view of regional, qualification and age structure of the active labour force. Basic research method is deduction method, because we start from the general towards special and individual, with the aim to bring human factor and development of agriculture in Montenegro into connection.

With regards to the key role of the human factor in the development of agriculture, a question emerges: is this factor in Montenegro a real opportunity or a constraint? Upon having insight into the existing situation of the human factor, we can conclude that there is an obvious discrepancy between demographic and economic centres. Expressed migration of the population from the north towards the south and from villages to cities brought the development of agricultural production into question. When the human factor engaged in agriculture is concerned, old population and elderly households prevail, which is a serious threat to the development, because depopulation and "senilization" caused abandoning villages, deagrarization and space devastation.
\end{abstract}

Key words: Human factor, Migration, Economy, Agriculture, Agrarian policy.

JEL: $J 43$

\section{Introduction}

Business efficiency and development of certain activity is conditioned by availability and proper combination of the production factors. Our determinant is that the human factor is the basic factor of the development (Dessler, 2007). Upon reviewing the dynamics and basic qualitative features of the population, we observe other factors of the development of agriculture in Montenegro as well. It is about natural conditions, supply of land, agricultural households,

1 Žarko Božović, Ph.D., Associate Professor, University of Montenegro, Faculty of Economics, Jovana Tomesevica street no. 37, 81000 Podgorica, Montenegro, Phone: +382 20241 138, E-mail: jocodj@gmail.com

2 Jovan Đurašković, M.A., Assistant, University of Montenegro, Faculty of Economics, Jovana Tomesevica street no. 37, 81000 Podgorica, Montenegro, Phone: +382 20241 138, E-mail: jocodj@gmail.com

EP 2014 (61) 1 (7-15) 
orchards and livestock, and also institutional frameworks where the agriculture is developed. It is necessary to determine achieved level of development, and based on that, to review possible directions of the development of agriculture and rural areas in Montenegro. While reviewing future directions, we primarily start from activities of Montenegro in integration processes of joining the European Union, which significantly defines the frame of the future development and according with that, achieving goals as well. Firstly, it is about sustainable resource management and producing good quality, healthy and safe food, providing quality standard for the population in rural areas, increasing competitiveness in food production at national and international market (Ministry of Agriculture, Water Management and Forestry, 2007).

In the context of reviewing the above title, we will take into consideration the significance of the village and agriculture for employing population in the conditions of the economic crisis.

\section{Montenegrin population as a factor of agriculture development}

Decisive determinant assumes that human factors are the basis of the economic development. In order to test this hypothesis, it is necessary to determine the human resources quality available in Montenegro and whether they are properly used. Population is the foundation, the base of the development of human factors (human resources), so it is necessary to analyse the dynamics and the basic structure of the population (Wren and Voich, 1994).

As a result of population growth and the mechanical movement (migrations) there are about 620,000 people in Montenegro (this is a permanent population, according to Census 2011, without persons working abroad). Without going into further analysis, we can conclude that the dynamics and achieved level of the population is primarily the result of decreasing birth rate and reduced mortality with which Montenegro reaches low natality areas. Migration processes also had a strong reflection of the population. We could notice population movement, i.e. migrations from the northern areas towards the central and southern part of Montenegro. This analysis highlights the obvious fact about migrations of professional and highly skilled human resources from Montenegro. These processes were especially triggered by economic and political events, starting from 1990's. The brain drain is not only the reduction, i.e. depletion of human resources base, but also a permanent loss of significant resources invested in education of the "finished" product. There is no doubt that the current crisis will influence the increase of drain of above mentioned category of the human resources, primarily because there is no clear national policy and strategy in this area. The decrease in birth rate which was caused by economic factors (unemployment) like getting married later, families with one or two children or reducing the number of household members are evidence of further decrease in natality. On the other hand, there is no official active population policy which would stimulate employment and increase of the members of households.

The results of the last census show unbalanced distribution of the population in municipalities and regions of Montenegro and discrepancy of economic and demographic focus. Twelve municipalities in Montenegro have decrease in population in 2011 with regards to 2003, not to mention settlements which were left without inhabitants. These are municipalities in the north 
and with municipality Cetinje in the central region of the country. Decrease in population in the northern area in Montenegro and increase in the central and southern part is the result of the migration within the country.

Absolutely, the number of inhabitants in Montenegro rose with regards to 2003 for 7762 inhabitants, whereas the population of the northern area has negative growth rate of $7.2 \%$, increase of population in the central part is $5.8 \%$ and it is $3.7 \%$ by the coast. There are 185,937 inhabitants in Podgorica only, which is almost $30 \%$ of total population. We are witnessing therefore, a universal "Podgorization" of Montenegro, both in terms of demographic and migration trends, and cause and effect in terms of investment and overall economic trends.

The following graph is illustrates comparative review or raise/fall of population in municipalities in 2011 with regards to 2003 and it is expressed in percentage.

Graph 1. Decrease or increase in population by municipalities in 2011 compared to 2003 year (in \%)

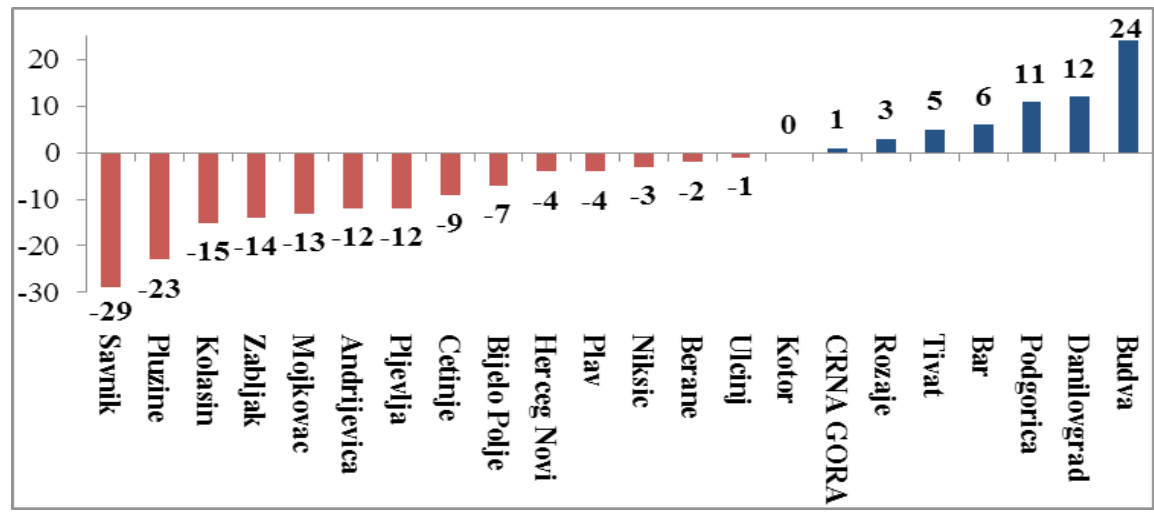

Source: Monstat, 2012.

Thus, as it was obvious, the biggest fall in population was recorded in the municipalities in the north of the country, whereas the growth of population was recorded in the southern and central regions (primarily in Podgorica and its vicinity).

After considering the movement of total number of population, we also observe basic elements and point to interdependence of dynamics and basic structures of the population. It is primarily about the gender and age structure. The results of the last census and the previous ones as well show a certain excess of female compared to male population, both on the national level and the municipalities.

Since the age structure is an index of quality of human factor, we also point out to the tendency of population aging, with obvious regional differences. It is about decreasing share of the young population, increasing share of middle aged population, and especially the old population over 60 years of age i.e. 65 years. 
Žarko Božović, Jovan Đurašković

Table 1. Age structure of Montenegrin population (\%)

\begin{tabular}{|c|c|c|c|c|c|c|}
\hline Year & Total & up to 20 years & $\mathbf{2 1 - 3 0}$ & $\mathbf{3 1 - 4 0}$ & $\mathbf{4 5 - 5 9}$ & $\begin{array}{c}\text { 60 years and } \\
\text { more }\end{array}$ \\
\hline $\mathbf{1 9 6 1}$ & 100 & 44.5 & 17.7 & 12.3 & 15.1 & 13.4 \\
\hline $\mathbf{1 9 7 1}$ & 100 & 42.8 & 14.9 & 14.2 & 17.7 & 11.1 \\
\hline $\mathbf{1 9 8 1}$ & 100 & 37.3 & 17.8 & 12.4 & 21.5 & 11.0 \\
\hline $\mathbf{1 9 9 1}$ & 100 & 33.6 & 15.9 & 15.0 & 21.9 & 13.6 \\
\hline $\mathbf{2 0 0 3}$ & 100 & 28.6 & 15.2 & 13.4 & 18.2 & 16.6 \\
\hline $\mathbf{2 0 1 1}$ & 100 & 26.3 & 14.3 & 13.9 & 20.6 & 18.3 \\
\hline
\end{tabular}

Source: Monstat, 2012.

In an analysis of the age of the population, the sixties of the last century can be characterized as the beginning of undesirable trends in the age structure of population, which is growing, whether it is about reducing the proportion of young people and increasing the relative share of the older population. In addition to this indicator, the tendency of aging of the population and level of "old age" illustrates that the average age tends to increase the apparent difference in municipalities and regions (UNDP, 2013).

Table 2. Average age of the population in municipalities, 2011.

\begin{tabular}{|l|c|c|c|}
\hline \multirow{2}{*}{ Municipalities } & \multicolumn{3}{|c|}{ Average age of the population } \\
\cline { 2 - 4 } & Total & Urban & Other \\
\hline Montenegro & 37.2 & 36.6 & 38.4 \\
\hline Pluzine & 43.7 & 38.2 & 47.5 \\
\hline Savnik & 42.5 & 37.9 & 43.9 \\
\hline Zabljak & 41.9 & 40.5 & 43.3 \\
\hline Pljevlja & 41.8 & 39 & 46.6 \\
\hline Cetinje & 40.3 & 39 & 47.2 \\
\hline Kolasin & 40.1 & 37.6 & 41.3 \\
\hline Herceg Novi & 40 & 40.1 & 39.7 \\
\hline Andrijevica & 39.9 & 38.1 & 40.3 \\
\hline Kotor & 39.5 & 39.8 & 39.1 \\
\hline Mojkovac & 38.4 & 37.4 & 39.1 \\
\hline Danilovgrad & 38.1 & 36.6 & 39.1 \\
\hline Tivat & 38 & 38.3 & 37.3 \\
\hline Bar & 37.9 & 37.8 & 37.9 \\
\hline Niksic & 37.8 & 37.1 & 40.2 \\
\hline Ulcinj & 37.8 & 36.8 & 38.8 \\
\hline Budva & 36.5 & 36.5 & 36.7 \\
\hline Berane & 36.4 & 36.9 & 36.1 \\
\hline Bijelo Polje & 36.1 & 35.1 & 37.1 \\
\hline Plav & 36 & 35.6 & 36.2 \\
\hline Podgorica & 35.7 & 35.3 & 37.5 \\
\hline Rozaje & 31.7 & 32.2 & 31.3 \\
\hline & & & \\
\hline
\end{tabular}

Source: Monstat, 2012. 
Across regions, the average age of the population is the largest in the north of Montenegro, apart from Rozaje. There are also significant differences in the relation city population and other settlements. City population is a bit younger, which is a result of migrations, whereas in other settlements of primarily rural type - the population age shows the influence of a range of factors, demographic and economic, which brought to senilization, rural depopulation, deagrarization and area devastation.

The full picture of human resource quality in Montenegrin agriculture is illustrated in the graph 2 .

Graph 2. Total labour force by age

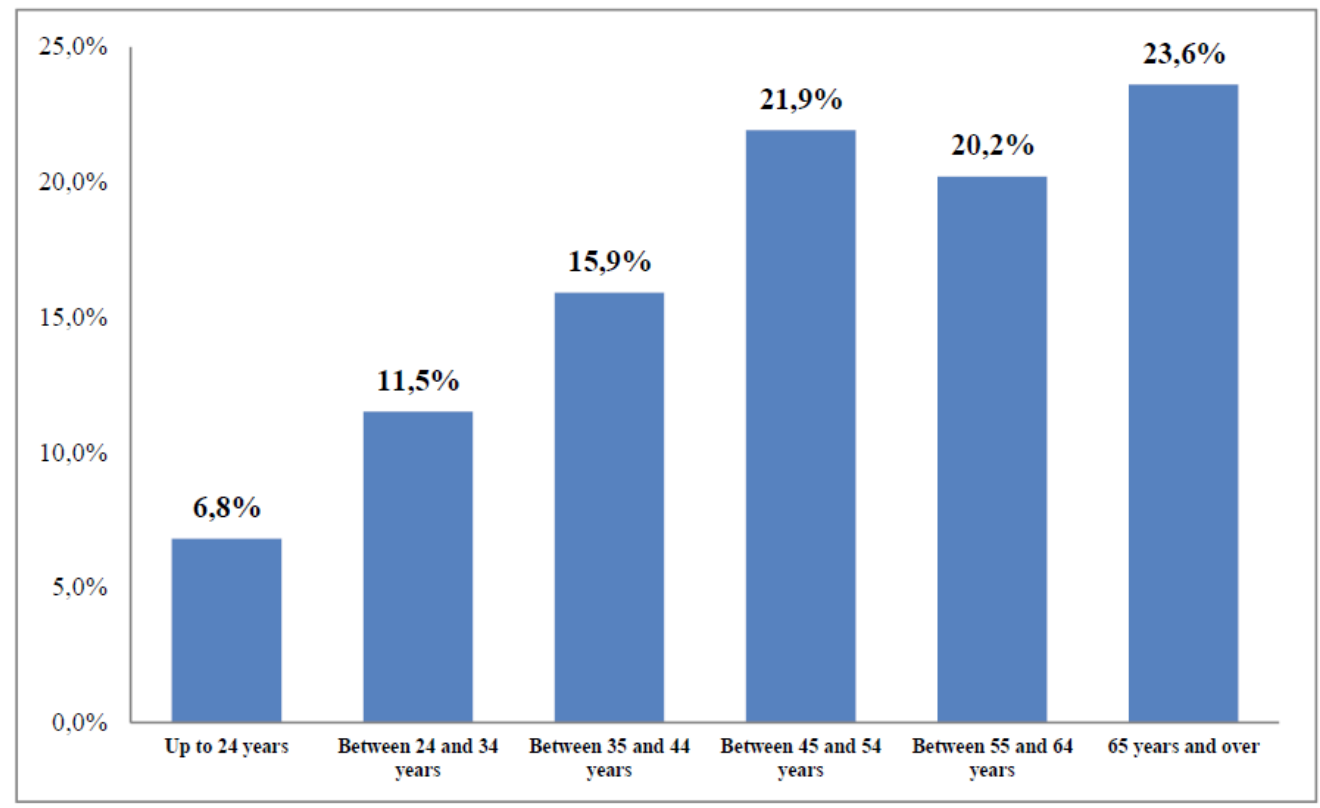

Source: Monstat, 2012.

When the human factor engaged in agriculture is concerned, old population and elderly households prevail, which is a serious threat to the development. On the total 48,824 holders of family agricultural holdings, the most of holders $(16,228)$ are aged 65 years and over, with the share of 33.24\% (Monstat, 2011b).

\section{Achieved level of development of agriculture in Montenegro}

Previously processed demographic development undoubtedly has a strong influence on the development of agriculture and rural parts of Montenegro, and primarily negative migration balance i.e. abandoning certain areas (in the northern and central parts) i.e. depopulation and demographic aging of population in villages. Significance of agriculture in socioeconomic development is not only measured by direct effects (contribution in GDP with around $11 \%$ ), but also with indirect effects which are being valorised in other activities, especially in tourism and catering, sustainable development and employment. 
Apart from population as the basic factor of the development of agriculture, other factors also play an important role, especially natural conditions (climate, soil etc.) as well as funds (funds of crop production, livestock production, etc.).

Agricultural land is the basic fixed capital in agriculture, and it comprises around 518ha or relatively 0.84 ha per capita. This resource takes part with $38 \%$ in total area of Montenegro, which is very important, especially if we take into account agricultural land per capita. On the other hand, the structure of this fund is unfavourable and represents an index of unreasonable usage of this important resource. Its structure can be viewed from the following review.

Graph 3. Structure of agricultural land of Montenegro

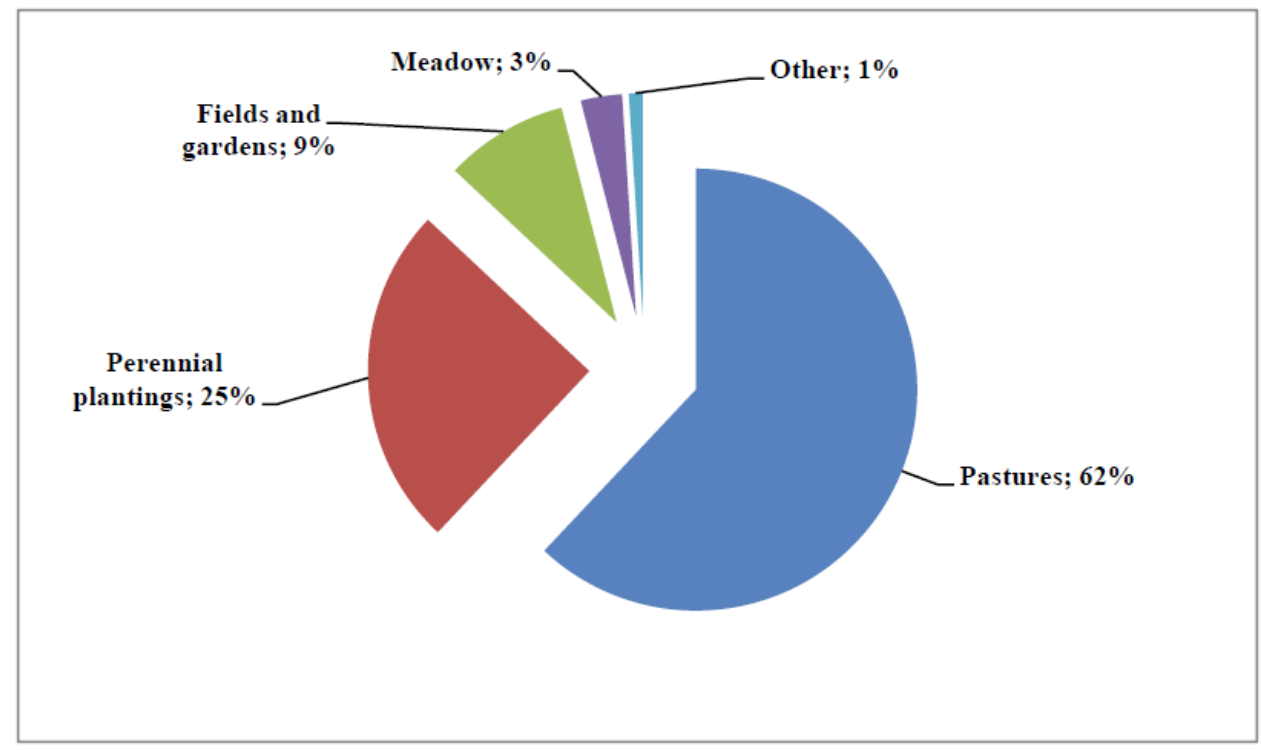

Source: Monstat, 2011a.

It is obvious that the participation of pastures prevails with over $60 \%$ and they are not used enough, and as a consequence the total production potential is not enough used as well. If we consider the fact that the agricultural production is taking place within 48,824 agricultural households, whereas only 46 subjects of agricultural production, we undoubtedly have a big number of households with small potentials, i.e. scattered homesteads which excludes rational production, especially with regards to the volume of economy. On the other hand, these households grow various crops and livestock.

As we have already pointed out, apart from the basic capital in agriculture, we should show one-year and perennial crops in viticulture and fruit production, and by the virtue of that production of grapes and wine, which is based on the quantity of over 10 million grapevines. Agriculture has already achieved remarkable results in this area because wine is recognized as a brand, and when Montenegro joins the European Union, it will create conditions for bigger production, more significant export and product quality. 
Product export will contribute to reduction of deficit of balance of payments and general import dependence.

Within crop production, we should mention tobacco production and its sale at the foreign market, then vegetable production, especially in the protected space which enables bigger productivity and in that way the competitiveness at the national and international market. Potato production also marks the increase, whereas the production of grains and fodder crops is negligible.

With regards to stock breeding, we have to point out that the livestock is significantly reducing, apart from swine, whereas the number of sheep is drastically dropping (from inventory to inventory), which is in the direct connection with expressed migration of the population and its aging, and with already determined discrepancies between natural potentials and human factor. It is certain that this trend is caused by decades-long, we can even say stepmother's attitude towards the village and agriculture and the absence of developmental agrarian policy.

The condition of the supply of land in the agriculture of Montenegro (unfavourable structure), a big number of small individual agricultural (old) households and unfavourable tendencies in production show that Montenegro does not use its products enough. Potentially, it is about serious obstacles in further development, better to say limitations, especially on the way towards the European integrations. Still, we should look for chances in creating future directions of the development of agricultural production in favourable institutional frameworks, in budget support by the state of Montenegro and European Union funds. We should count on reducing import dependence in the future period, because Montenegro is net importer of agricultural products which is shown by the high deficit of almost $30 \%$.

\section{Possible directions of the development of agriculture of Montenegro}

Analysis of the dynamics and structure of the human factor, natural factors, institutional framework, create a real basics for reviewing future directions of the development of agriculture in Montenegro. Namely, each prediction has to be real with certain dose of optimistic scenario. Due to accepted internal and external, economic and technical factors, our assumption is that there are real conditions for increasing agricultural production based upon modernization and generally development of rural areas. Development of agriculture is the priority of the developmental policy of Montenegro. Increasing production and strengthening its market attributes are expected in crop production (fruit, wine, potatoes, vegetables, tobacco and olives) and stock breeding (milk, dairy products, meat). In order to achieve this goal, we need budget support and the support from international funds to raise the product quality and creating conditions for working and living in villages. Without motivation of agricultural producers, especially the young ones, there is no increased agricultural production, or good quality products, i.e. satisfying the customers' needs. It is about a feedback loop: motivation of the human factor - good quality product - satisfied consumer and producer (Marusic, 2006). These are basic assumptions for joining the European Union and using EU funds, when it is necessary to work on constant education of human resources who are agricultural professions and agricultural producers in general. 
The certainty of realization of the above mentioned directions of development depends largely on the skill and the intensification of work on weaknesses manifested in their work so far, and that is primarily: non-competitive price of agricultural products, low level of mechanization, the irrationality of agricultural production due to high cost of inputs, low level of market sales, unsatisfactory level of quality standards, inadequate structure and poor infrastructure in rural areas. On the other side, it is necessary to intensify activities towards strengthening advantages that agricultural production in Montenegro has. In that sense, we have to support employing people in the agricultural sector, which has always been an absorber in reducing the unemployment, especially in the periods of crisis. We are encouraged by the information (Ministry of Agriculture) that around 450 new jobs have been opened in this sector.

Institutions that deal with the development of agriculture play an important role in the plan of technological development, modernization of agricultural production and achieving the goals from the Strategy of the development of agriculture. We primarily think of the Ministry of Agriculture and its role in the framework of agrarian policy and its implementation. Then, there is veterinarian service which is in charge of health protection, breeding and animal trade. Also, professional help of these institutions is needed on-site, especially in the area of education and organization of profitable agricultural production. The role of professionals is irreplaceable in the development of agriculture as an industry.

\section{Conclusion}

Previous review of the situation and future directions of the development of agriculture in Montenegro undoubtedly imposes a conclusion that agriculture and rural development are priority directions of this area. It is so especially if we take into account its multiple effects on other activities, above all on tourism and catering, and also on the employment and broader social-economic development.

Secondly, human factor is the key development factor, whether we talk about total population or population which is active in agriculture, and also professional, highly professional and academic staff. Upon having insight into the existing situation of the human factor, we can conclude that there is an obvious discrepancy between demographic and economic centres. Expressed migration of the population from the north towards the south and from villages to cities brought the development of agricultural production into question. When the human factor engaged in agriculture is concerned, old population and elderly households prevail, which is a serious threat to the development, because depopulation and "senilization" caused abandoning villages, deagrarization and space devastation.

For sure, basic assumption is creating basic postulate of management of human resource "right person at the right place". Age structure of the population and its insufficient spatial distribution, with discrepancy between demographic centres and other resources is a limitation for the development of agriculture in Montenegro. 
The chances of development of agriculture and rural areas in Montenegro can be seen in: quality crop and livestock production, i.e. healthy and good quality food; bigger marketing orientated production with competitive prices at the national and international market; active agrarian policy which will be stimulant for agricultural producers, especially young people, and this will contribute to increased production and reducing the unemployment.

\section{References}

1. Dessler, G. (2007): Osnovi menadžmenta ljudskih resursa, Data status, Beograd, Srbija.

2. Marušić, S. (2006): Managing human potentials, Adeco, Zagreb, Hrvatska.

3. Ministry of Agriculture, Water Management and Forestry (2007): Montenegrin agriculture and European Union: Strategy of development of food production and rural areas, Podgorica, Montenegro.

4. Statistical office of Montenegro - MONSTAT (2011a): Agricultural Census 2010, Key Variables - Land and Livestock Resources, Podgorica, Montenegro.

5. Statistical office of Montenegro - MONSTAT (2011b): Agricultural Census 2010, Structure of Agricultural Holdings, Podgorica, Montenegro.

6. Statistical office of Montenegro-MONSTAT (2012): Uporedni pregled broja stanovnika, Podgorica, Montenegro.

7. UNDP (2013): Nacionalni izvještaj o razvoju po mjeri čovjeka 2013, UNDP Montenegro, Podgorica.

8. Wren, D. A., Voich, D. (1994): Management, Poslovni sistem, Grmeč AD, Privredni pregled, Beograd, Srbija. 
